\title{
Юридичні аспекти лікарських помилок у хірургічній практиці
}

\author{
А. М. Біляков ${ }^{1}$, Н. М. Ергард ${ }^{1}$, О. Л. Кобилянський ${ }^{2}$
}

${ }^{1}$ Національний медичний університет імені О. О. Богомольця, м. Київ,

²Державний університет інфраструктури та технології, м. Київ

\section{Judicial aspects of physician's mistakes in surgical practice}

\author{
A. M. Biliakov ${ }^{1}$, N. M. Erhard ${ }^{1}$, O. L. Kobylianskyi ${ }^{2}$ \\ 'Bogomolets National Medical University, Kyiv, \\ ${ }^{2}$ State University of Infrastructure and Technology, Kyiv
}

\section{Реферат}

Мета. Аналіз лікарських помилок та їх судово-медичної складової, що є основною для визначення міри кримінальної відповідальності лікаря-хірурга у разі спричинення шкоди здоров’ю пацієнта.

Матеріали і методи. Методологічною основою роботи стали системно-структурний та порівняльний аналіз лікарських помилок у медичному та правовому аспектах, обгрунтування понять «лікарська помилка», «нещасний випадок» та «професійний злочин». Розглянуто положення та сформульовано висновки, які грунтуються на широкому нормативному, науково-теоретичному і практичному матеріалі.

Результати. Помилки в медичній практиці досить поширені, навіть у розвинених країнах світу. Судова практика щодо цієї категорії справ узагалі не оприлюднюється, що не лише негативно впливає на збільшення кількості лікарських помилок, а й дає лікарю можливість відчувати впевненість у своїй безкарності. В Україні професійна діяльність лікаряхірурга регламентована відомчими наказами, стандартами та правилами надання медичної допомоги, а також окремими статтями Кримінального кодексу України, в яких йдеться про особливості та специфіку медичної діяльності та пов'язану з нею кримінальну відповідальність, і лише стаття 140 стосується будь-якого лікаря, у тому числі й хірурга. Висновки. На нашу думку, актуальною та обгрунтованою є пропозиція багатьох фахівців у галузі медичного права щодо необхідності визнання лікарської помилки юридичною категорією і внесення ії до чинного законодавства. Саме тоді, коли лікарська помилка стане складовою нормативно-правової бази медичної діяльності, пацієнти та лікарі матимуть можливість повноцінно захищати себе в суді.

Ключові слова: хірургія; лікарські помилки; тяжкі наслідки; судово-медична експертиза.

\section{Abstract}

Objective. Analysis of physicians' mistakes and their forensic component, which determine the measure of criminal responsibility of surgeon-physician in a case of causing of harm to the patient's health.

Materials and methods. Methodological background of the work was a systemic-structural and comparative analysis of physician's mistakes in medical and legal aspects, substantiation of definitions of «physician's mistake», «accident» and «professional crime». The provisions considered and conclusion formulated were based on broad regulatory, scientifically-theoretical and practical material.

Results. Mistakes in medical practice are fairly prevalent, even in the developed states of the world. Judicial practice, concerning this category of deals is generally not advertised, what not only negatively impacts on enhancement of quantity of physician's mistakes, as well as gives to physician possibility to feel confidence in their impunity. In Ukraine a professional activity of physician-surgeon is regulated by departmental Acts, standards and rules of the medical aid delivery, as well as by certain articles of Criminal codex of Ukraine, in which are mentioned the peculiarities and specificity of medical professional activity with connected criminal responsibility, and only article 140 is addressed to any physician, including surgeon.

Conclusion. By our opinion, proposition of majority of specialties, based on actual and substantiated material in a field of medical legacy, concerns the necessity of recognition of a physician's mistake as a judicial category and its introduction into actual legislation. So on, when physician's mistake would be incorporated into regulatory-legal base of medical activity, the patients and physicians would have possibility to defend their selves adequately in court.

Keywords: surgery; physician's mistakes; severe consequences; forensic expertise.

Запровадження медичної реформи та перехід на нові стандарти надання хірургічної допомоги передбачають покращення якості лікування. Однак стандарти містять алгоритм лікування та діагностики в залежності від складності і доступності пропонованих методів без урахуван- ня економічної складової щодо можливості проведення цих заходів. Також підвищені вимоги до медичного персоналу та його діяльності можуть спричинити зростання кількості як діагностичних, так і лікувальних помилок, за якими в медичному товаристві закріпилася назва «лікар- 
ські помилки». Але в кримінальному та цивільному законодавстві України немає визначення поняття «лікарська помилка», тому розуміння лікарської помилки викликае значну дискусію в правовій та медичній сфері.

Мета дослідження: аналіз лікарських помилок та їх судово-медичної складової, що є основною для визначення міри кримінальної відповідальності лікаря-хірурга у разі спричинення шкоди здоров'ю пацієнта.

\section{Матеріали і методи дослідження}

Проаналізовано процесуальне законодавство України, Кримінальний кодекс України (надалі - КК України), Цивільний кодекс України, Закон України «Про захист прав споживачів», постанови Кабінету Міністрів України, відомчі накази та інструкції, розпорядження МВС України, Мін'юсту України, МОЗ України, які регламентують як судово-експертну діяльність, так і виконання професійних обов'язків. Методологічною основою роботи стали системно-структурний та порівняльний аналіз лікарських помилок у медичному та правовому аспектах, обгрунтування понять «лікарська помилка», «нещасний випадок» та «професійний злочин». Розглянуто положення та сформульовано висновки, які грунтуються на широкому нормативному, науково-теоретичному і практичному матеріалі.

\section{Результати}

В Україні професійна діяльність лікаря-хірурга регламентована відомчими наказами, стандартами та правилами надання медичної допомоги, а також статтями 131, 132, 138 - 145 КК України, у яких йдеться про особливості та специфіку медичної діяльності та пов'язану з нею кримінальну відповідальність. Зокрема, статті 131, 132 КК України містять норми щодо зараження вірусом та розголошення цих відомостей, статті 141, 142 - норми, які стосуються незаконних клінічних випробувань та дослідів, статті 143, 144 - норми, які стосуються трансплантації та донорства, стаття 154 - норми, які стосуються розголошення лікарської таємниці, і лише стаття 140 - норми, які стосуються будь-якого лікаря, у тому числі хірурга [1].

Згідно зі статтею 140 КК України неналежне виконання медичним або фармацевтичним працівником своїх професійних обов'язків внаслідок недбалого чи несумлінного до них ставлення, якщо це спричинило тяжкі наслідки для хворого, карається позбавленням права обіймати певні посади чи займатися певною діяльністю на строк до п'яти років або виправними роботами на строк до двох років, або обмеженням волі на строк до двох років, або позбавленням волі на той самий строк.

Поняття «недбале та несумлінне ставлення до своїх обов'язків» $є$ цілком визначеним і передбачає невиконання посадових інструкцій чи їх виконання не в повному обсязі відповідно до чинних стандартів та нормативів.

Тривалий час точиться дискусія щодо визначення поняття «тяжкі наслідки», адже від цього принципово залежить юридична оцінка дій лікаря. Більшість провідних юристів-законотворців України вважає тяжкими наслідками завдану шкоду здоров'ю, яка з точки зору судово-медичної експертизи відповідає тяжким та середньої тяжкості тілесним ушкодженням. Згідно з пунктом 2.1.1 Правил судово-медичного визначення ступеня тяжкості тілесних ушкоджень, затверджених Наказом МОЗ України від 17 січня 1995 р. № 6, ознаками тяжкого тілесного ушкодження $є$ небезпека для життя, втрата будь-якого органа або втрата органом його функцій, душевна хвороба, розлад здоров'я, поєднаний зі стійкою втратою працездатності не менш ніж на одну третину, переривання вагітності, невиправне знівечення обличчя. А згідно з пунктом 2.2.1 ознаками тілесних ушкоджень середньої тяжкості є тривалий (строком понад 3 тижні) розлад здоров'я чи стійка втрата працездатності менше ніж на третину (втрата загальної працездатності від 10 до 33\%) [2].

Однак законодавство у сфері медичної діяльності має певні особливості, адже діяльність лікаря пов'язана з ризиками, що можуть спричинити не лише тяжку шкоду здоров’ю, а й смерть. Зокрема, відповідно до статті 39 «Крайня необхідність КК України не є злочином заподіяння шкоди правоохоронюваним інтересам у стані крайньої необхідності, тобто для усунення небезпеки, що безпосередньо загрожує особі чи охоронюваним законом правам цієї людини або інших осіб, а також суспільним інтересам чи інтересам держави, якщо цю небезпеку в даній обстановці не можна було усунути іншими засобами і якщо при цьому не було допущено перевищення меж крайньої необхідності. Наприклад, лікар-хірург хворому, який мав ураження великої судини, виконав не судинну пластику, а ампутацію, що зберегло життя пацієнту, однак, з точки зору судово-медичної експертизи, спричинило тяжку шкоду здоров'ю. У такому разі важливо розуміти, що небезпека в даній ситуації не може бути відвернена чи усунена іншим шляхом, окрім заподіяння шкоди, та усунення небезпеки відбулося без перевищення меж крайньої необхідності.

Крім того, слід звернути увагу на статтю 42 КК України, згідно з якою не є злочином діяння, яке заподіяло шкоду правоохоронюваним інтересам, якщо це діяння було вчинене в умовах виправданого ризику для досягнення значної суспільно корисної мети. Це стосується перш за все розроблення та впровадження інноваційних методів лікування, хірургічних тактик та прийомів. Однак, незважаючи на добровільну згоду пацієнта, якщо мета могла бути досягнута відомим та перевіреним шляхом, у разі заподіяння шкоди здоров'ю через ризикований медичний експеримент дії лікаря будуть кваліфіковані за статтею 140 «Неналежне виконання професійних обов'язків медичним або фармацевтичним працівником" КК України.

Аналіз експертної (судово-медичної) практики показує, що помилки лікарів-хірургів можуть мати діагностичний, технічний, організаційний та деонтологічний характер [3].

Діагностичними є помилки в розпізнанні захворювання та оцінюванні ускладнень, наприклад, помилковий діагноз.

Помилки в проведенні діагностичних та лікувальних маніпуляцій та процедур визначають як технічні. Якщо 
пацієнту встановлено правильний діагноз, але лікувальну тактику обрано неправильно, це вважають лікувальнотактичною помилкою, і саме в цій ситуації судово-медичний експерт буде вирішувати, чи є прямий або непрямий причинно-наслідковий зв'язок між діями лікаря-хірурга і наслідками для пацієнта.

Можливі помилки в організації надання тих чи інших видів медичної допомоги, у забезпеченні необхідних умов функціонування, наприклад, хірургічної служби у районних лікарнях або в умовах надзвичайного стану.

Нині на сході України відбуваються заходи Операції об'єднаних сил. Саме в умовах війни виникає велика кількість організаційних помилок у наданні медичної допомоги. У хірургів, яким необхідно надати медичну допомогу потерпілим особам, обмаль часу для того, щоб повноцінно описати морфологічні особливості ушкодження в медичній документації, через що втрачається можливість у майбутньому встановити характер і давність заподіяння тілесного ушкодження військовослужбовцю в рамках проведення судово-медичної експертизи. Деонтологічні помилки, які пов'язані з поведінкою, спілкуванням лікаря з хворим чи його родичами, на жаль, займають не останне місце. Вони обумовлені обмеженням часу лікаря-хірурга для спілкування з конкретним хворим, що регламентовано медичними реформами, які відбуваються в Україні.

У відповідності до пункту 3 «Правил проведення комісійних судово-медичних експертиз в бюро судово-медичної експертизи», затверджених Наказом МОЗ України від 17.01.1995 р. № 6, судово-медичні експертизи «лікарських справ» проводяться у відділі комісійних судовомедичних експертиз бюро судово-медичної експертизи з метою встановлення правильності надання медичної допомоги у разі притягнення до кримінальної відповідальності медичних працівників за «професійні правопорушення» [2].

Саме в рамках проведення судово-медичної експертизи приймаються рішення щодо правильності надання хірургічної допомоги, оцінюються доцільність та повнота діагностичних методів, обраних хірургом під час надання медичної допомоги потерпілому, обгрунтовується обрана тактика лікування та визначаються позитивні і негативні наслідки ії проведення. Вирішують ці питання обов'язково комісії у складі експертів і залучених лікарів-хірургів, які в даному разі набувають статусу експертів і несуть відповідальність за обгрунтованість та повноту свого висновку, а також за експертні помилки, як і судово-медичні експерти.

У ході проведення експертизи часто помилки можуть бути виявлені під час перевірки головою експертної комісії, а так само будь-яким їі членом. Найчастіше помилки виявляють на синтезуючій стадії та стадії формулювання висновків. Якщо члени експертної комісії не в змозі дійти єдиного висновку, вони мають право зробити кожен свій окремий висновок у рамках проведення однієї судово-медичної експертизи, і тоді кожен член експертної комісії у суді доводить обгрунтованість та повноту са- ме свого висновку. Давати правову оцінку судово-медичній експертизі мають право лише органи досудового розслідування та судді.

\section{Обговорення}

Науковці в різні періоди часу пропонували багато класифікацій та визначень поняття лікарської помилки. Ми схиляємось до більш відомої класифікації Ю. Т. Комаровського (1976), яка має деталізований характер та об'єднує лікарські помилки в декілька рубрик. За видом: діагностичні (за захворюваннями і ускладненнями, за якістю і формулюванням діагнозів, за розбіжністю вихідного і заключного діагнозів); лікувальні (загальні, технічні, тактичні); організаційні (адміністративні, документаційні, деонтологічні); за причинами: суб'єктивні (моральні та фізичні вади, недостатня професійна підготовка лікаря, недостатній збір і аналіз інформаціі); об'єктивні (несприятливі особливості пацієнта і його захворювання, несприятлива зовнішня обстановка, недосконалість медичної науки і технологій); за наслідками: нетяжкі (тимчасова втрата працездатності, непотрібна госпіталізація); тяжкі (непотрібне лікування, інвалідність, смерть); за категоріями, їх критеріями і покладеною відповідальністю: омана; нещасний випадок (можливий під час виконання обов'язків лікаря, покарання немає); проступок (у разі порушення лікарських обов'язків і нетяжких наслідків помилки, можливі адміністративне розслідування і дисциплінарні санкції; злочин (у разі порушення обов'язків лікаря і тяжких наслідків помилки, можливе кримінальне розслідування і покарання) [4].

Відомі дещо інші визначення лікарської помилки з точки зору права, а саме помилка лікаря в професійній діяльності внаслідок добросовісної омани за відсутності недбальства, халатності або невігластва, тобто за відсутності складу злочину, або неправильна дія (або бездіяльність) лікаря, основою якої є недосконалість сучасної медичної науки, незнання або невміння використати наявні знання на практиці [5].

Повертаючись до статті 140 КК України, слід зазначити, що відповідальність за нормою цієї статті не передбачається у разі, коли тяжкі наслідки для хворого стали результатом недостатніх навичок, досвіду і кваліфікації медичного або фармацевтичного працівника. Це обумовлено законодавчим поєднанням об'єктивного та суб'єктивного критеріїв злочинної недбалості як виду необережної форми вини, про що зазначено в коментарі до статті 25 КК України [1]. Тобто запропоновані поняття лікарської помилки виключають кримінальну відповідальність, передбачену статтею 140 КК України.

Розглянемо дану норму закону на прикладі. Пластичний хірург без відповідного досвіду та достатніх професійних навичок виконав пластичну операцію на обличчі пацієнтки. Внаслідок проведеного оперативного лікування у неї на обличчі виникли великі значно помітні рубці. Було проведено судово-медичну експертизу і встановлено прямий причинно-наслідковий зв'язок між діями пластичного хірурга та їх наслідками у потерпілої. У да- 
ній ситуації суб'єктивні обставини підтверджують необережну форму вини через недостатній досвід роботи лікаря, і він не несе кримінальної відповідальності за статтею 140 Кк України, а потерпіла особа має право витребувати компенсацію моральної та матеріальної шкоди лише в цивільно-правовому полі. Та сама ситуація, але згідно із затвердженими в лікувальній установі посадовими інструкціями та рівнем медичної кваліфікації пластичний хірург не міг виконувати операцію такої складності. У даному разі наявні об'єктивні обставини злочину, тобто неналежне виконання медичним працівником своїх професійних обов'язків через недбале чи несумлінне до них ставлення. У цій ситуації хірург несе відповідальність за статтею 140 КК України.

На практиці тлумачення даної норми дає можливість стороні захисту кваліфікувати дії лікарів як добросовісну оману, що виключає кримінальну відповідальність.

Від лікарських помилок необхідно відрізняти такі поняття, як «нещасний випадок» та «професійний злочин». До нещасних випадків у медицині можна віднести невдалі наслідки, які неможливо передбачити та які не залежать від лікарських помилок, а можуть бути пов'язані з нетиповим перебігом хвороби, індивідуальними особливостями організму, відсутністю умов для надання медичної допомоги тощо. Для юридичного доведення нещасного випадку в медичній практиці необхідно виключити наявність професійної помилки або професійного злочину [6]. На думку більшості юристів, такі ситуації слід відносити лише до категорії нещасного випадку і надавач медичної послуги має бути звільненим від відповідальності. Але відповідно до статті 906 Цивільного кодексу України (надалі - ЦК України) відповідальність медичних закладів, які надають медичні послуги за оплату, здійснюючи підприемницьку діяльність, грунтується на принципі об'єктивної відповідальності, тобто незалежно від їх вини, якщо не доведено, що належне виконання виявилось неможливим внаслідок непереборної сили [7].

У статті 614 ЦК України передбачено вину як підставу відповідальності за порушення зобов'язання. Особа, яка здійснювала лікування пацієнта з порушенням взятих на себе зобов'язань, несе відповідальність, коли таика доведено іï вину (необережність чи умисел). Цією ж статтею врегульовано ситуацію, коли відповідальність не настає, а саме: коли лікар доведе, що вжив всіх залежних від нього заходів щодо належного виконання обов'язків [7]. Перелік таких ситуацій складений на підставі аналізу лікарських помилок, що виникли не через безвідповідальне ставлення хірурга до своєї роботи, а внаслідок впливу непередбачуваних чинників: несприятливого збігу обставин; наявності чинників, які наукою ще не пояснені; недосконалості медичної техніки, а також фармацевтичних препаратів, які не лише впливали на організм позитивно, а й викликали негативні побічні ефекти) [7].

Теоретично можливі ситуації, коли лікар, керуючись власними поглядами та маючи прямий умисел, наприклад на грунті релігійних, політичних чи расових пере- конань, через недбале ставлення до своїх обов'язків спричинив тяжку шкоду здоров'ю пацієнта, тоді він несе кримінальну відповідальність за статтею 121 КК України за умисне тяжке тілесне ушкодження [1].

Якщо в негативних наслідках лікування є вина не лише лікаря-хірурга, а й самого пацієнта, лікар-хірург не несе відповідальності за статтею 140 КК України. Також частиною шостою статті 10 Закону України «Про захист прав споживачів» передбачено можливість звільнення від відповідальності лікаря, якщо лікарська помилка сталася з вини пацієнта. Рішення про звільнення лікаря-хірурга як надавача медичних послуг від відповідальності суд приймає лише в тому разі, коли доведено факт неналежного виконання зобов'язань з боку паціента як замовника медичних послуг [8].

\section{Висновки}

1. Проведений аналіз дає підставу для висновку, що наразі на медичного працівника покладена висока міра відповідальності і дотепер тривають дискусії щодо можливостей притягнення лікаря до кримінальної чи цивільної відповідальності.

2. Актуальною та обгрунтованою $€$ пропозиція багатьох фахівців у галузі медичного права щодо необхідності визнання лікарської помилки юридичною категорією і внесення ії до чинного законодавства. Саме тоді, коли лікарська помилка стане складовою нормативно-правової бази медичної діяльності, у пацієнтів та у лікарів з'явиться можливість повноцінно захищати себе в суді.

3. 3 точки зору цивільно-правового аспекту, за лікарські помилки, в основі яких лежать суб'єктивні причини, необхідно передбачити персональну відповідальність медичного працівника, а не медичної установи в цілому. Лише в такому разі пацієнт матиме можливість отримати матеріальну та моральну компенсацію не від лікувальної установи, а шляхом подання регресного позову до конкретного лікаря.

\section{Підтвердження}

Фінансування. Фінансування наукової роботи за кошти авторів.

Інформація про внесок кожного учасника. А. М. Біляков - збір матеріалів статті, написання тексту; Н. М. Ергард - обробка матеріалів статті, написання тексту; О. Л. Кобилянський - аналіз отриманих даних, написання тексту. Всі автори прочитали і схвалили остаточний варіант рукопису.

Конфлікт інтересів. Автори, які взяли участь в цьому дослідженні, декларують відсутність конфлікту інтересів щодо цього рукопису.

Згода на публікацію. Всі автори дали згоду на публікацію цього рукопису.

\section{References}

1. Kryminalnyi kodeks Ukrainy [Internet]. [onovleno 2019 sich. 01; tsytovano 2019 sich. 22]. Available from: https://zakon.rada.gov.ua/laws/ show/2341-14. [In Ukrainian]. 
2. Nakaz MOZ Ukrainy № 6 «Pro rozvytok ta vdoskonalennia sudovomedychnoi sluzhby Ukrainy» [Internet]. [onovleno 1995 sich. 17; tsytovano 2019 sich. 22]. Available from: https://zakon.rada.gov.ua/laws/ show/z0254-95. [In Ukrainian].

3. Antonov SV. Medychna pomylka: yurydychnyi aspekt. Medychne pravo. 2008;(10):94-6. [In Ukrainian].

4. Komarovskyi YuT. Metodolohichni osnovy pomylok. Klin khir. 1976;(9):52-62. [In Ukrainian].

5. Antonov SV. Likarska pomylka yak osoblyvyi kryterii pry vstanovlenni vyny medychnykh pratsivnykiv i tsyvilno-pravovi delikty. In: Derzhava i pravo: Zb. nauk. prats Inst. derzhavy i prava im. V. M. Kostenko NAN Ukrainy. 2002;18:224-9. [In Ukrainian].
6. Seniuta II. Medychne pravo: pravo liudyny na okhoronu zdorov'ia. Lviv: Astroliabiia; 2007. 224 s. [In Ukrainian].

7. Tsyvilnyi kodeks Ukrainy [Internet]. [onovleno 2003 sich. 16; cit 2019 sich. 22]. Available from: https://zakon.rada.gov.ua/laws/show/43515. [In Ukrainian].

8. Zakon Ukrainy «Pro zakhyst prav spozhyvachiv» [Internet]. [onovleno 2019 sich. 01; cit 2019 sich. 22]. Available from: https://zakon.rada.gov. ua/laws/show/1023-12. [In Ukrainian].

Надійшла 24.01.19 